\title{
Tyrphostin AG 825
}

National Cancer Institute

\section{Source}

National Cancer Institute. Tyrphostin A G 825. NCI Thesaurus. Code C1688.

A member of the tyrphostin family of tyrosine kinase inhibitors, which selectively inhibits HER2. (NCl) 